\title{
Manuscript Research about Effect of Application of Career Stage Systems on the Natural Work Satisfaction in PGI "C" Hospital Jakarta
}

\author{
Labora Sitinjak \\ Doctoral Program, Human Resource Management, State University of Jakarta \\ Jl. Rawamangun Muka, RT.11/RW.14, Rawamangun, Jakarta Timur, 13220 \\ E-mail: Sintinjak.labora@yahoo.com \\ Hady Efendy (Corresponding author) \\ Education Practice and Academic Consultant \\ E-mail: efendy_hady@yahoo.co.id
}

Received: July 12, 2017 Accepted: July 26, 2017 Online published: August 4, 2017

doi:10.5296/ijhrs.v7i3.11528 URL: https://doi.org/10.5296/ijhrs.v7i3.11528

\begin{abstract}
Career stage is a system which can enhance job satisfaction, work performance and professionalism of nurse through competence enhancement. The component of career stage system being researched included career development, appreciation to the nurse, opportunity for doing challenging task, opportunity for promotion and recognition of the nurse. Nurse career stage system at PGI "C" Hospital in Jakarta has been known since seven years ago in which nurse expects this system to be implemented, however there is no decision as to implement the system yet. The study was aimed to evaluate the influence of the applied of career system for job satisfaction of the nurses in PGI "C" Hospital in Jakarta. The design used was quasy experiment in pre and posttest with control group, which the intervention was given at $\mathrm{H}$ Unit and as control group was Renal Unit. By using purposive sampling 21 nurses was selected in each unit. Data collection was twice, i.e before intervention and 7 weeks after intervention. The statistic used are t-test, correlation and one way Anova. The result showed that in the intervention group, the improvement of job satisfaction of the nurses higher with p-value: 0.000 for all components of career stage system (career development, appreciation to the nurse, opportunity for doing challenging task, opportunity for promotion and recognition of the nurse). The study concluded that the implementation of the career stage system could
\end{abstract}


improve the job satisfaction of the nurses at PGI "C" Hospital in Jakarta. Based on this result to enhance the quality of nursing services at PGI "C" Hospital in Jakarta, it is suggested to the director to implement this system.

Keywords: Career stage, job satisfaction, nurse.

\section{Background}

In the era of globalization, a lot of changes occur both science, technology and changes in the mindset of society. The public demand for the quality and professionalism of health services is increasing. Nursing as a profession and nurses as professionals are also required to be responsible in providing nursing services in accordance with competence and authority possessed independently or in cooperation with other health team members.

Nurses as one health worker plays an important role in achieving health development goals. Even the World Health Organization (WHO) states that nurses are "back bone" to achieve global, national and local targets. This is because the nurse is a health worker with the largest proportion, serving patients for 24 hours continuously and continuously and is at the forefront in providing health services to the community. Career level is a system to improve the performance and professionalism of nurses according to their work field through the improvement of competence. Professional nurses currently recognized in Indonesia are graduated from D-3 Nursing graduates and will continue to increase.

The rationale for the preparation of the career ladder of the nursing profession departs from the interests of the profession to be responsible and accountable in providing nursing care. At each career level, nurses have certain competencies in providing nursing care so it can be accounted for. Career level is needed for the realization of nursing care of the quality considering the nurses have the most power and the longest accompany patient. With the guaranteed quality of nursing care provided by the nurse in accordance with the competence they have, it will contribute to the quality of hospital services. With the establishment of competence nurses at each level, will facilitate the recruitment, selection, orientation, development and development of human resources (HR) nursing.

Directorate General of Medical Services of the Ministry of Health of the Republic of Indonesia (2006) proposed career development system and awards for nurses not fully competency-based and not yet a unit with health care system in hospital. Nurse's career development system in the context of the current award, especially for Civil Servants (PNS) is through the rules of functional position of nurses stipulated through Decree of the Minister of Administrative Reform (SK MENPAN) No: 94/KEP/M.PAN/II/2001, SKB MENKES with KA.BAKN NO : 733/MENKES/SKB/VI/2002 and Decision of the minister of health (KEPMENKES) No: 1280/MENKES/SK/X/2002. In fact, although some regulations have been fixed but the performance of nurses is still low, nurse placement has not been based on competence, its development has not been based on a clear career pattern and promotion has not been based on real work performance.

From 2002 to the end of 2008, seven out of fourteen post-graduate residency students of the Faculty of Health Sciences at the University of Indonesia at PGI "C" Hospital Jakarta have 
identified and discussed the problem of the absence of a career nurse system. In the result of study of residency student of 2002 about nursing career system found $76 \%$ of respondents said there is no nursing career system at PGI "C" Hospital Jakarta and 54\% said that the nurse has not satisfied working in PGI "C" Hospital Jakarta (Sitompul, 2002). Head of Nursing said that the head of nursing has submitted proposal of preparation of the implementation and the concept of nurse career ladder system to the head of hospital but has not yet issued a Decision Letter for the implementation of the system because it still asks whether there is influence of the application of career ladder system will give job satisfaction on the nurse and Can improve the quality of nursing service? In the final presentation of the residency students at PGI "C" Hospital Jakarta in December 2007, the hospital leader expects to do research on the effect of applying career ladder system so that there is objective data that can be used as consideration to apply the career ladder system.

\section{Materials and Methodology}

The purpose of research to see the effect of the application of career ladder system to nurse job satisfaction in PGI "C" Hospital Jakarta. The study design used quasi experiment in the form of pre and post test with control group with one unit for intervention group and one unit for control group. In the intervention group, training and application of nurse career ladder system and in the control group without training and nursery career system implementation were applied. The study design is illustrated in the following table:

Table 1. Research Design

\begin{tabular}{|l|c|c|c|}
\hline & Pre test & & Post test \\
\hline Intervension Group & $\mathrm{K} 1$ & $\mathrm{X}$ & $\mathrm{K} 2$ \\
\hline Control Group & $\mathrm{K} 3$ & & $\mathrm{~K} 4$ \\
\hline
\end{tabular}

The study was conducted on two units of nursing service of one unit as intervention group and one more unit as control group. The study population is all nurses working on nursing services. The research sample is all nurses who are actively working in two service units with education criteria of Nursing Education School (SPK), Nursing Diploma III (DIII) and Nursing Graduate (S1) and willing to become research respondents $(\mathrm{n} 1=\mathrm{n} 2=21)$. The data were collected in two stages before intervention and seven weeks after the intervention.

\section{Results and Discussion}

\subsection{Results}

Based on equality test of respondent characteristic between intervention group and control group it was concluded that the characteristics in both groups of respondents were equal. Thus, if an intervention is made to one of the groups and there are different effects on both groups, it can be concluded that the difference occurs because of the intervention given. The effect of the application of career ladder system on nurse job satisfaction in table 2 shows that in the intervention group, job satisfaction differed significantly between pre and post intervention with p-value: 0.000 ( $\mathrm{p}<0.05)$. The difference in nurse job satisfaction increase 
from before intervenís to after intervention ranged between $49 \%$ - $60 \%$.

Table 2. Differences of Average Values of Job Nurses Satisfaction LevelBefore \& After Intervention in the intervention group (2008)

\begin{tabular}{|c|c|c|c|c|c|c|c|}
\hline \multirow{2}{*}{ Variabel } & \multirow{2}{*}{ Intervention } & \multirow{2}{*}{ Mean } & \multicolumn{2}{|c|}{ Delta of Mean } & \multirow{2}{*}{ DS } & \multirow{2}{*}{$\mathrm{t}$} & \multirow{2}{*}{ p-value } \\
\hline & & & Amount & $\%$ & & & \\
\hline \multirow{2}{*}{$\begin{array}{l}\text { Career } \\
\text { Development }\end{array}$} & Before & 20,7 & \multirow[t]{2}{*}{12,2} & \multirow{2}{*}{60} & \multirow{2}{*}{3,5} & \multirow{2}{*}{16,112} & \multirow{2}{*}{0,000} \\
\hline & After & 32,9 & & & & & \\
\hline \multirow{2}{*}{ Appreciation } & Before & 20,5 & \multirow[t]{2}{*}{12,0} & \multirow{2}{*}{49} & \multirow{2}{*}{3,1} & \multirow{2}{*}{17,566} & \multirow{2}{*}{0,000} \\
\hline & After & 32,5 & & & & & \\
\hline \multirow{2}{*}{$\begin{array}{l}\text { Challenging } \\
\text { Jobs }\end{array}$} & Before & 17,8 & \multirow{2}{*}{9,9} & \multirow{2}{*}{56} & \multirow{2}{*}{2,9} & \multirow{2}{*}{15,881} & \multirow{2}{*}{0,000} \\
\hline & After & 27,7 & & & & & \\
\hline \multirow{2}{*}{$\begin{array}{l}\text { Promotion } \\
\text { Opportunity }\end{array}$} & Before & 24,2 & \multirow[t]{2}{*}{12,7} & \multirow{2}{*}{52} & \multirow{2}{*}{3,7} & \multirow{2}{*}{15,551} & \multirow{2}{*}{0,000} \\
\hline & After & 36,9 & & & & & \\
\hline \multirow{2}{*}{ Recognition } & Before & 21,2 & \multirow{2}{*}{11,0} & \multirow{2}{*}{52} & \multirow{2}{*}{3,4} & \multirow{2}{*}{14,965} & \multirow{2}{*}{0,000} \\
\hline & After & 32,2 & & & & & \\
\hline
\end{tabular}

Note: DS = Deviation Standard

Increased nurse job satisfaction after intervention occurs in all components of the career path system (career development: 60\%, rewards: 49\%, challenging jobs: 56\%, promotional opportunities: $52 \%$ and recognition: $52 \%$ ). P-value for all components: 0,000. These results show a very significant increase from before to after intervention in the intervention group. Differences in mean values of nurses' job satisfaction to career development, rewards, challenging work, promotion and recognition of nurses after intervention between intervention groups and control groups are shown in table 3 below.

Table 3. Differences of Average Values Level of Job Satisfaction Nurse after Intervention Between Group Intervention with Control (2008)

\begin{tabular}{|c|c|c|c|c|c|c|}
\hline \multirow{2}{*}{ Variabel } & \multirow{2}{*}{ Group } & \multirow{2}{*}{ Mean } & \multicolumn{2}{|c|}{ Delta of Mean } & \multirow{2}{*}{$\mathrm{t}$} & \multirow{2}{*}{$\mathrm{p}$-value } \\
\hline & & & Amount & $\%$ & & \\
\hline \multirow{2}{*}{$\begin{array}{l}\text { Career } \\
\text { Development }\end{array}$} & Intervention & 32,9 & \multirow{2}{*}{13.7} & \multirow{2}{*}{71} & \multirow{2}{*}{19,155} & \multirow{2}{*}{0,000} \\
\hline & Control & 19,2 & & & & \\
\hline \multirow{2}{*}{ Appreciation } & Intervention & 32,5 & \multirow{2}{*}{12.9} & \multirow{2}{*}{66} & \multirow{2}{*}{15,409} & \multirow{2}{*}{0,000} \\
\hline & Control & 19,6 & & & & \\
\hline \multirow{2}{*}{ Challenging Jobs } & Intervention & 27,7 & \multirow{2}{*}{11,0} & \multirow{2}{*}{66} & \multirow{2}{*}{14,708} & \multirow{2}{*}{0,000} \\
\hline & Control & 16,7 & & & & \\
\hline \multirow{2}{*}{$\begin{array}{l}\text { Promotion } \\
\text { Opportunity }\end{array}$} & Intervention & 36,9 & \multirow{2}{*}{15.1} & \multirow{2}{*}{69} & \multirow{2}{*}{18,323} & \multirow{2}{*}{0,000} \\
\hline & Control & 21,8 & & & & \\
\hline \multirow{2}{*}{ Recognition } & Intervention & 32,2 & \multirow{2}{*}{12.5} & \multirow{2}{*}{63} & \multirow{2}{*}{12,574} & \multirow{2}{*}{0,000} \\
\hline & Control & 19,7 & & & & \\
\hline
\end{tabular}

P-value for career development, rewards, challenging jobs, promotion and recognition opportunities is $<0.05$, meaning that there is a significant change after intervention between intervention and control groups. In this change there was a very high increase in nurse job 
satisfaction in the intervention group over the control group. Increased nurse job satisfaction after intervention in the intervention group occurs in all components of the career path system (career development: $71 \%$, awards: $66 \%$, challenging jobs: $66 \%$, promotional opportunities: $69 \%$ and recognition: $63 \%$ ). These results show a very significant increase after intervention between the intervention group and the control group.

\subsection{Discussion}

The results of research on the effect of applying the career ladder system to the nurses' job satisfaction in table 2 support the opinion of Craven and Himle (2000), that the mastery of a knowledge and skill, obtained through learning process or a teaching and practice. Mangkunegara (2000) \& Mangkuprawira (2002) stated that staff development activities including education and training to improve knowledge, attitudes and special skills are essential for the smooth implementation of tasks. Furthermore it is said that training is a short-term educational process using systematic and organized procedures in which staff learn knowledge and technical skills for a defined purpose. The continuous learning mechanism in nursing practice can be implemented in a planned manner in the nurse career ladder system.

Different types of training can be used in training of health professionals, including nursing professional training such as structured training in clinical training at the mechanism of the career path system. Factors to be considered in the training according to Mangkunegara (2000) \& Mangkuprawira (2002) include high motivation to learn, active participation during training, clear, measurable training objectives as well as training materials as per the objectives to be achieved.

The results of the analysis and some of the above explanation can be concluded that the implementation of nurse career ladder system in this study is very influential on improving nurse work satisfaction in the intervention group. Increased nurse job satisfaction is significant in every component (career development, reward, challenging work, promotion and recognition opportunity to nurse) from before to after applying nurse career ladder system. Improvement also occurs according to the theory of job satisfaction based on Two Factor Theory presented by Herzberg in Griffin (2004), Equity Theory developed by Adams in Griffn, 2004. Discrepancy Theory proposed by Porter in As'ad (2003) and Maslow's Hierarchy of Needs Maslow in Griffin (2004) and factors affecting job satisfaction proposed by Blum in As'ad (2003), Locke in As'ad (2003), Parasuraman (1990), Davis (1996), Wesley \& Jackcls in As' Ad (2003), William in Kuswadi (2004), Muchlas (1999), Swansburg (2000), Arikhman (2001), Robbins (2006), Siagian (2002), As'ad (2003), Hasibuan (2003), Kuswadi (2004), Parwanto \& Wahyudin (2008), Wikipedia Indonesia (2008) \& Robbins in Wikipedia (2008). Job satisfaction allows increased work productivity so as to provide high quality nursing care.

The difference of nurse's job satisfaction level toward career development, awards, challenging work, promotion and recognition opportunity of nurse after applying nurse career ladder system in intervention group with post test in the control group revealed that $\mathrm{p}$-value for all career ladder component ie career development, Rewards, challenging jobs, 
promotional opportunities and recognition of nurses are $<0.05$. Thus there was a significant increase in nurse job satisfaction after intervention in the intervention group versus posttest in the control group. Gibson (1996) states the most widely used method of staff productivity development is a program designed to improve knowledge, attitude, and skills. He also believes that training using demonstration methods or direct application will improve one's work performance.

In career development, the mean score in the intervention group was 32.9, while in the control group 19.2, the difference in job satisfaction 13.7 increased $42 \%$ job satisfaction in the intervention group. Nursing career development is beneficial to develop the nurse's self-esteem, minimize turn over, motivate talent development, reduce subjectivity in promotion, give future career certainty and support the organization to obtain skilled and skilled nurses (Sulistiyani \& Rosidah, 2003). The nursing career development program is obtained through the nurse's self and the assessment of her work environment by job analysis. Leaders who plan to develop their careers nurses will produce highly motivated nurses to achieve according to the level they expect. According to Van Maanem \& Scheim in Marquis (2000) there are four levels of successful career development programs that provide opportunities for nurses through exploration, early development (probation, improve performance), early development (additional training), evaluation Self-ability, career retention and preparation to end a position.

In the reward component, the mean score in the intervention group was 32.5 , while in the control group 19.6 with the difference in job satisfaction 12.9 increased by $40 \%$ nurse work satisfaction in the intervention group. Swansburg (2000) says that the career ladder system allows for awards through the achievement of expected competencies, thereby affecting hikes and increasing revenue. The career ladder system provides recognition and appreciation through increased responsibility and accountability in nursing care. In addition a person at a certain level may act as a trainer or as a role model for inexperienced nurses (Cumming \& Loveridge, 1996). The opportunity given to the nurse performing the tasks motivated by continuous career enhancement is a tribute that will encourage him to remain more accomplished over time. The awareness of a possible expectation coupled with the pathways available to him from the organization will lead to the achievement of that expectation.

In the challenging work component, the mean score in the intervention group was 27.7, while in the control group 16.7 with the difference in job satisfaction 11 increased by $40 \%$ of the nurse's work satisfaction in the intervention group. At each career nurse level has been determined the expected competence and gradually increasingly complex, meaning that the higher one's career ladder the greater the responsibility. Marquis (2000) suggests that planned work experience is the most powerful means of career development through assignment to different units, rotation or the opportunity to be in charge. This situation can be a challenge for nurses to continue to grow. Robbins (2006) says that work with a bit of a challenge will create boredom, on the contrary if too many challenges can be frustrating and a feeling of failure. Generally employees will experience the pleasure and satisfaction of working on the challenge with a moderate level of work challenge is planned. 
In the promotion component, the mean score in the intervention group was 36.9, whereas in the control group 21.8 with the difference in job satisfaction 15.1 increased $41 \%$ nurse work satisfaction in the intervention group. Hasibuan (2001) says that promotion is a recognition and confidence in the abilities and skills of employees occupy a higher position. Deckert et al (1984) \& Ilyas (2001) also said that career paths are based on clinical competitiveness in which a person is promoted to a higher level after meeting the prescribed criteria. Giving greater responsibility to the task is a form of horizontal promotion (Hageman in Ilyas, 2001). The results of Dweyer et al's study in Leo Bunga (2001), nurses with high autonomy options and increased career ladder will show improvement in job satisfaction. This statement is reinforced by Benner (1984) that the promotion of clinical career paths is the right and proper promotion not just a salary increase but can provide new challenges and variations in the role of nurse so that those who are promoted are someone who has performed well.

In the recognition component, the mean score in the intervention group was 32.2, whereas in the control group 19.7 with the difference in job satisfaction 12.5 increased $39 \%$ nurse work satisfaction in the intervention group. Tomey (1996) says that the career ladder system creates recognition of clinical excellence. This is supported by Bener (1984) \& Kron (1987) that the nurse career ladder system enhances the recognition of other professions of the nurse's role as nursing care provider to the client. Nurses gain job satisfaction in learning new skills and receive recognition based on their performance and career abilities. Robbins (2006) says an effective form of recognition is to provide an opportunity to participate in decision-making processes, increasing authority and autonomy over their work lives. Thus the nurse who has a good performance, need to get recognition from the management to maintain and even improve its performance.

\section{Conclusion}

Good job satisfaction of nurse will increase work productivity and impact to improve the quality of nursing service. In this study stated that the implementation of career path system has a significant effect on the increase of nurse work satisfaction. Based on these results to improve the quality of nursing service in PGI "C" Hospital Jakarta it is advisable to apply nurse career ladder system based on hospital management decision.

The relationship of this study with nursing education is better nurse career system is introduced since prospective nurses are on the bench of education so that learners understand the career ladder nurse. Thus prospective nurses begin to be motivated to plan and prepare for a career that wants to achieve later.

\section{References}

As'ad. (2003). Seri ilmu sumber daya manusia: Psikologi industri. Cetakan kesembilan. Yogyakarta: Liberty.

Blum, M. L., \& Naylor, J. C. (1986). Industrial psychology: Its theoretical and social foundation. New York: Herper \& Row.

Chanafie, D. (2005). Hubungan persepsi perawat pelaksana tentang jenjang karier dengan 


\section{Al Macrothink}

International Journal of Human Resource Studies

ISSN 2162-3058

2017, Vol. 7, No. 3

kepuasan kerja di RSUD "Budhi Asih" Jakarta. Tesis. Jakarta: FIK UI. (Tidak dipublikasikan).

Creswell, J. W. (2003). Research design: Pendekatan kualitatif \& kuantitatif. (KIK UI angkatan III, IV \& Khabibah N., penerjemah). Edisi kedua/edisi revisi. Jakarta: KIK UI Press. (Sumber asli diterbitkan 1994).

Cumming \& Loveridge. (1996). Nursing management in the new paradigm. Maryland: Aspen Publication Inc.

Davis, K., \& Newstrom. (1985). Human behavior at work: Organizational behavior, $7^{\text {th }}$ ed. Jakarta: Erlangga.

Departemen Kesehatan RI. (1999). Pedoman uraian tugas tenaga perawat di rumah sakit. Jakarta: Depkes RI.

Departemen Kesehatan RI. (2000). Kebijakan pengembangan tenaga kesehatan. Jakarta: Depkes RI.

Departemen Kesehatan RI. (2003). Indikator indosehat Pedoman uraian tugas tenaga perawat di rumah sakit. Jakarta: Depkes RI.

Departemen Kesehatan RI. (2006). Pedoman pengembangan jenjang karier profesional perawat. Jakarta: Depkes RI.

Gibson, et al dalam Dharma A. (1996). Organisasi: Perilaku, struktur, proses. Cetakan kesembilan. Jakarta: Erlangga.

Gillies, D. A. (1996). Nursing management: A system approach. Third edition. Philadelphia: W.B. Saunders.

Girsang, O. (2006). Analisis kinerja perawat pelaksana di ruang rawat inap rumah sakit PGI "C" Jakarta. Tesis. Jakarta: FIK UI. (Unpublished).

Griffin, R. W. (2004). Manajemen, judul asli: Management, alih bahasa: Gina Gania, edisi ketujuh, jilid 2, Jakarta: Erlangga.

Handoko, T. H. (1999). Manajemen personalia dan sumber daya manusia. Edisi kedua. Yogyakarta: BPEE.

Hariningsih, W. (2008). Implementasi kinerja perawat di rumah sakit, pendidikan dan komunitas. http://www.pelkesi.or.id. Accessed 2008, 31 January.

Harley, (1980 dalam Sipahutar, M.A. (2008). Keperawatan profesional. http://www.google.wikipedia. Accessed 2007, 22 November.

Hasibuan, H. H. S. P. (2003). Manajemen sumber daya manusia. Edisi revisi. Jakarta: Bumi Aksara.

Huber, d. (2000). Leadership and nursing care management. $2^{\text {nd }}$ ed. Philadelphia: W.B. Saunders. 


\section{Macrothink}

International Journal of Human Resource Studies

ISSN 2162-3058

2017, Vol. 7, No. 3

Hutabarat, L., \& Kusnanto, H. (2007). Persepsi pengembangan karier perawat: Studi kasus di RSUD Abepura. http://www.lrc.kmpk.ugm.ac.id. Accessed 2008, 31 Januari.

Ilyas, Y. (2002). Kinerja: Teori, penilaian dan penelitian. Cetakan ketiga. Depok: Pusat Kajian Ekonomi Kesehatan FKM UI

Ilyas, Y. (2004). Perencanaan SDM rumah sakit: Teori, metoda dan formula. Cetakan kedua. Depok: FKM UI.

Kron, T. (1987). The management of patient care: Putting leadership skills to work. $6^{\text {th }}$ ed. Philadelphia: W.B. Saunders Company

Mangkunegara, A. P. (2000). Manajemen Sumber Daya Manusia Perusahaan. Bandung: PT. Remaja Kosdokarya

Mangkuprawira, S. T. (2002). Manajemen Sumber Daya Manusia Stratejik. Jakarta: Ghalia Indonesia.

Marquis, B. L., \& Huston, C. J. (2000). Leadership roles and management function in nursing: Theory application. $3^{\text {rd }}$ ed. Philadelphia: Lippincott.

Mariner, T. (1996). Guide to nursing management. St. Louis: Mosby Year Book.

Marrelli, T. M. (1993). The nurse manager's survival guide: Practical answers to everyday problems. USA: Mosby.

Moekijat. (2007). Pengembangan dan penilaian hasil kerja. Cetakan kesatu. Bandung: Sumber Indah.

Muchlas, M. (1999). Perilaku organisasi. Yogyakarta: Aditya Media.

Mulyadi. (2007). Sistem Terpadu Pengelolaan Kinerja Personel Berbasis Balanced Scorecard. Cetakan pertama. Yogyakarta: UPP STIM YKPN.

Munandar, A. S. (2004). Psikologi industri dan organisasi. Jakarta: UI-Press.

Pabundu, T. (2006). Budaya organisasi dan peningkatan kinerja perusahaan. Cetakan pertama. Jakarta: PT. Bumi Aksara.

Parasuraman, et al. (1990). Delivery quality service: Balancing costumer perception and expectations. New York:The Fee Pers.

Parwanto \& Wahyuddin. (2008). Pengaruh faktor-faktor kepuasan kerja terhadap kinerja karyawan pusat pendidikan komputer akutansi IMKA di Surabaya. http://www.Irc.kmpk.ugm.ac.id. Accessed 2008, 31 January.

Porter, O. G., Timothy, Finnigon \& Sharon. (1984). Shared government for nursing: A creative approach to professional accountability. Maryland: Aspen Publication.

Praptianingsih, S. (2006) Kedudukan hukum perawat dalam upaya pelayanan kesehatan di rumah sakit. Edisi 1. Jakarta: PT. Rajagrafindo Persada. 
Prayetni \& Tetuko, B. (2008). Sering pindah tugas menghambat perawat berspesialisasi. (2008, 31 Januari) http://www.jawapos.co.id.

Rachmat, R. H. H. (2006). Perencanaan SDM kesehatan secara nasional dalam kaitannya dengan pengembangan tenaga perawat. Bahan kuliah. Jakarta: FIK UI. Tidak dipublikasikan.

Robbins, S. P. (2006). Perilaku organisasi. (Molan B., penerjemah). Edisi kesepuluh/edisi bahasa Indonesia. PT Indeks kelompok Gramedia. (Sumber asli diterbitkan 2003).

Siagian, S. (2002). Manajemen sumber daya manusia. Cetakan kesembilan. Jakarta: P.T. Bumi Aksara.

Siagian, S. P. (2004). Teori motivasi dan aplikasinya. Cetakan ketiga. Jakarta: PT Andi Mahasatya.

Sitompul, R. (2002). Laporan residensi kepemimpinan dan manajemen keperawatan di RS PGI “C” Jakarta. FIK UI. (Unpublished).

Soecipto, B. W dkk. (2002). Paradigma baru manajemen sumber daya manusia. Yogyakarta: Amara Books.

Stamps, P. L. (1997). Nurses and work satisfaction: An index for measurement. Chicago: Health administration Press Chicago Millionis.

Sugiyono. (2005). Statistika untuk penelitian. Bandung: C.V. Alfabeta

Sulistiyani, A. T., \& Rosidah. (2003). Manajemen sumber daya manusia: Konsep, teori dan pengembangan dalam konteks organisasi publik. Cetakan pertama. Yogyakarta: Garaha Ilmu.

Susana A. (2007). Pengalaman tentang aplikasi sistem jenjang karier perawat di RS "Immanuel" Bandung. Komunikasi personal dalam studi banding, 1 November 2007 di Bandung: RS “Immanuel” Bandung.

Swansburg, A. C. (1996). Management and leadership for nurse managers. London England: Jones and Bartlett Publishers International.

Tappen, R. M. (1993). Nursing leadership and management: Concept and practice. $3^{\text {rd }}$ ed. Philadelphia: F.A. Davis Company.

Tjiptono, F. (1997). Prinsip total quality service. Yogyakarta: Penerbit Andi Yogyakarta.

Vecchio, R. P. (1995). Organizational behavior. $3^{\text {rd }}$ ed.. Orlando: Harcourt Brace College publishers.

\section{Copyright Disclaimer}

Copyright for this article is retained by the author(s), with first publication rights granted to the journal.

This is an open-access article distributed under the terms and conditions of the Creative Commons Attribution license (http://creativecommons.org/licenses/by/4.0/). 